\title{
Research on advertising art in New Media Era
}

\author{
Mingzhen Zhou \\ Yantai Nanshan University \\ Yantai, China
}

\begin{abstract}
In the era of new media, due to the emergence of digital and network technology, new media advertising propagation mode represented by networks, mobile TV, mobile phones is produced and develops in amazing speed. In this trend, how the advertising planners or enterprise to stay clear-minded, get a clear understanding of the situation, analyze and study the advertising art accurately, make the most suitable advertising planning and transmission mode, is particularly important. This article is aimed at analyzing the development and present situation of new media advertising through the discussion of new media and new media advertising features and puts forward the strategy of advertising enterprise innovation management based on the main problems of the new media advertising. This article also discussed how advertisers survive and develop in the big waves of new media era.
\end{abstract}

keywords-new media advertising; art features; development strategy

\section{NEW MEDIA CONCEPT}

The term of "new media" first appeared in the United States in 1967. There is no consensus on the concept of new media in the academic circles till now, magazine of "wired" in the United States believes that new media is "the spread from all people to all people". Wang Bin, Secretary General of new media industry alliance, has his definition that new media is the media with innovative forms, featured by interactive communication, based on digital information technology. Wei Wuhui, Vice President and CEO of BlogBus.com defines new media as a media form, by which audience could make an extensive and in-depth participation mainly through the digital mode. Some other scholars define new media as "interactive digital multiple-media ", although it is very difficult to have a complete consistent view, one point for sure is that new media is the extension of various media forms built on the basis of digital technology and network technology.

New media is evolving concept, its meaning will develop as the advances of media technology. It is an age category from the perspective of history of human communication. Therefore, new media concept is slightly different in different historical periods, each form of the media when it just show up, is known as new media compared to the previous forms of media. Contemporary new media is featured mainly by the invention of the computer and network technology. There is huge difference with traditional media in terms of the dissemination and contents.
For the time being, new media is a form of communication which provides users video, audio, voice and data services, online game, distance education combined with information and entertainment services using digital TV technology, network technology via internet, broadband local area networks, wireless communication networks and satellite channels, TV, computer and mobile phone terminals. Currently, seven types of media form was usually classified as new media column:

- Mobile digital TV (including wireless of, vehiclemounted)

- Cable digital television

- IPTV (based on TV terminal narrowly)

- Network broadcast

- Network TV (this is fastest developed new media)

- Phone TV

- Mobile TV (some of them are the digital form of traditional media).

\section{DEVElopment History AND PRESENT SituAtion OF NEW MEDIA ADVERTISING ART}

New media advertising refers to the advertising on the new media. Mainly include: Internet advertising, outdoor new media advertising, mobile terminal advertising

\section{A. Development History of New Media}

Prototype of the online advertising: The first one who transmitted advertising messages via the Internet using newsgroup spam is United States Somerset-Kent law firm in Phoenix, Arizona. On April 12, 1994, they sent more than 7,000 newsgroups adverting of Immigrant visa legal advisory services. But they were strongly condemned by public opinion, at the same time, many Internet service providers refused to provide services to them and put them in the blacklist of bad users. The short-lived battle of messages opened the prelude of the Internet advertising and people also learned that the loss of mandatory spam transmit outweighs the gain. Official birth: First time recognized banner, the first successful Internet advertising is "hot line" Web site, the site was founded in 1994, is the online version of print magazine of "the plane". They creatively use the "banner ad" form. This is a banner image file of $468 * 60$ pixel. Advertisers are United States telephone and Telegraph Company, viewers embraced this style of advertising. "Hot 
line" website started online shipping United States telephone and Telegraph Company's advertising In November 27, 1994. Online advertising in China begins on March 1997, the first commercial ads appear in China's network, Chinabyte, it is a $468^{*} 60$ pixel animated banner ads. Inter and IBM is one of the earliest domestic advertisers on the Internet.

\section{B. The Development Status of New Media Advertising}

In 2012, the size of global advertising market is expected to reach $\$ 542$ billion. Asia Pacific area and Latin America is expected to become the fastest growing region in forecast period, the spending growth is about two times of the world, the largest growth potential of which is from china. According to the prediction of market reach company, eMakter, global online advertising market in 2012 will grow as the speed of $21.3 \%$, reaching USD107 billion, while China is expected to become the main driving force to promote the growth of online advertising and overall advertising spending growth. China's online advertising spending in 2012 will reach \$7,36billoion, this growth trend will enable China to overtake Britain and Japan in 2014, being the second largest online advertising market. The development of new media advertising enjoys great prospect.

In recent years, the rapid development of new media advertising has deeply affected and changed the national and global media market layout, creating a myth of advertising industry. However, we should also be clear that, there are many problems need to be solved in the development of new media advertising. The fundamental cause of these problems is that new media advertising is in the primary stage of development. Lack of public trust in the network advertising, the difficulty in cultivating audience's loyalty, false and fraudulent advertising, missing of legal supervision system, unfair competition is the main problems. There are also many unfair competitions in the network advertising, mainly is to present his own content on other people's website forcibly by using of the hyperlink technology to split the web page window. The competition of network market is increasingly intense. Baidu VS 360 battle and Sogou VS 360 fight reflected this phenomenon. Legal supervision system is not in place. New media advertising is a rapid developed new thing. China's current laws and regulations for new media advertising as well as the relevant regulatory system are unsound. The main problem is the unclear of advertising subject. In China's current "advertising law", the definition of the main body of the advertising is based on that identity of advertisers, advertising operators and advertising publishers and their respective responsibilities and obligations is clear. However, network advertisement broke the boundaries, in many cases, two of them combined or even three become one. Therefore, the priority of regulating the network by legal means is to redefine the subject of advertising. Lack of creativity in new media advertising, homogenization is serious. Creativity is the source of advertising life and net advertising demands greater creativity, the creative focus is: interactive experience of online advertising, to break through the existing forms of advertising, strengthen the user experience, creative consciousness of user authorization.

\section{FEATURES OF NEW MEDIA ADVERTISING}

The biggest difference between new media and traditional media is the change of communication means: from "one point to multipoint" to "multipoint to multipoint. Some researchers posed the view from another prospective: new media release information by almost zero cost, it is free for the audience, which is a challenge to the costs of traditional media news production." Some outstanding features compared to traditional media is as following:

\section{A. Interactivity}

"Multi point to Multi Point" proposed by Guo Weihua, illuminates the meaning of interactivity in a very clear and very simple way, this is the most prominent feature of new media advertising. The receiver can carry out various forms of interaction by using modern advanced communication technology while traditional media can only passively accept, which makes the way of communication has changed fundamentally.

\section{B. Popularity}

Compared with the single way of traditional media, any network or mobile phone users could communicate through their own platform due to various ways of new media dissemination, which also makes any person in the platform could become the subject of media. At the same time, communication content could not be accurately manipulated in new media era, blog and the major forums fully explained this nature.

\section{Cross Time and Space}

One newspaper for one day, it means readers can only read today's news. One new episode for one day, it means audience can only see today's episode. If you want to see earlier news or television drama a few years ago, new media will undoubtedly have a unique advantage. Characteristic of space is also obvious, it is difficult to imagine the traditional media can become a unified global information network, but it could be in the new media due to the advantages of Internet.

\section{Diversification}

The content richness and diversification covered by new media makes the singleness and immobilization of traditional media looks like a boat in the sea, so small and so thin. Blogs, forums enables everyone could become the information releaser. The discussion of all kinds of life, learning, work in such a vast ocean of information with an unprecedented breadth and depth, almost reveals all cultural forms the human.

\section{DEVElopMENT STRATEGy OF ADVERTISING ART IN NEW MEDIA ERA}

The impact of new media technologies development on the audience is extremely profound, not less than significant transformation in dissemination history. How the advertising planners plan advertising for these new 
advertising audience ? I think we should focus on the individual freedom which has been greatly improved as followings:

\section{A. Respect Advertisement Audience's Autonomy}

China Internet Network Information Center and Japan Dentsu's investigation have shown that the vast majority of Internet users hate "pop-up" ads. They even download the software to turn off pop-up ads automatically. For new advertising audience, we should respect their autonomy and guide their desire to buy.

\section{B. Pay Attention to the Entertainment of Advertising}

The traditional dull, inflexible advertising form could no longer attract consumers' attention. The fast-paced lifestyle and mass information contact make new consumers more and more likely to pursue "fashion" "individuality" and keen on the Kuso culture which is characterized by deconstructing the solemnity and authority .Therefore, under the new media era, advertisement should mainly display the entertainment. Now more and more online games begin to implant advertising, even some of the game props looks like the commodity in real life.

\section{Pay Attention to the Participation of Consumers}

In Web2.0 time, participation type marketing could fully motivate the consumers' participation enthusiasm. It could effectively transmit the marketing information to tens of thousands of target customer at a very low cost and investment. It can be said that this is "new" and "light" weapons for brand marketing and product promotion. Such as Pepsi's "I'm going to be on it" activities, consumers can upload personal photos through the website, If you win in the vote, you can demonstrate your elegant demeanor in Pepsi Cola's jar. Such as HP's "my computer, my stage" activity, It can make the participants, especially college students users show their own ideas and create painting works on the Internet. These activities have met the needs of young people to show themselves and extend individuality and creativity. Not only demand is multi-level, different consumers' demand is also different. Therefore, it is necessary to make good interactive experience design according to his own characteristics and the core need of target audience.

\section{Pay Attention to the Long Tail Market}

The Internet reduces the interaction cost and information cost among people. Satisfaction of personal basic needs triggers increase of individualized requirement. As a result, the long tail market shows the trend of increasing and expanding. Nowadays consumers "individuality" gradually becomes the mainstream. If the enterprise wants to stand firm in the market, it must pay enough attention to the long tail consumers. Enterprises can guide the long tail of audience and adopt effective marketing strategy through "word of mouth promotion", establishing a system of recommendation

\section{E. Community Marketing}

The interaction and feedback between the advertiser and consumers is important, but more important is to form the interaction between the consumers. In the eyes of the consumer, they will never be in the equivalent position with the enterprises. It is easier for consumers to communicate advertising information. Community represents a small minority. It takes a group of audience base on common interests, hobbies, self-perception together, and gathers on the Internet and other media. In the community, the interpersonal relationship is more closely and the source is relatively real, also information is more easily accepted by the community. In addition, each community all has one "the spokesman". They are the authority who is recognized by the community person. Although the advertising audience behavior is becoming more and more personalized, it is still in a "authority worship" state unconsciously. If advertisers can timely find these communities and find the community representatives, thus they can carry on the systematic guidance to the representatives and create viral marketing within the community. This is undoubtedly a new communication strategy.

\section{CONCLUSION}

New media changes quickly. It promotes the rapid development of the media industry. This makes the commercial advertisers invest more and more on the new media. Media's meteoric rise and growth is profoundly changing the advertising art. Advertising is subject to the biggest impact of the new media, which is a manifestation of difference between old and new communication technologies. It is also the inevitable result of people's information view newly shaped by communication technology. In this new media era of information explosion, enterprise, organization and individual are slowly being surrounded by new media advertising. We, advertisers must keep pace with the times to develop advertising art better in new media era.

\section{REFERENCES}

[1] Zhang Liguo. Modern Design Aesthetics [M]. Henan Fine Arts Publishing House, 2007

[2] Huang Qiangling. Discussion on Value Characteristic and Development of Modern Design Aesthetics [J].Art \& Design, 2004 (09)

[3] Li Leshan. Aesthetics and Design [M].Xi'an Jiaotong University Press 2010

[4] Kan Tai-keung. Chinese and Western Civilization and Contemporary Chinese Design. [J].China Advertising, 2014, （04） 